埼玉累立がんセンター部外科

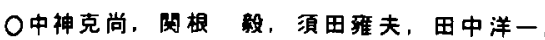

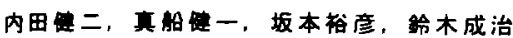

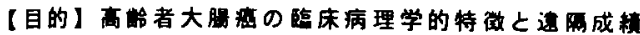
について検封した．【对象】1975年11月から1992年12月

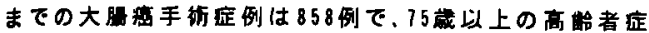
例（A群)105例を対家とし、74藏までの症例（B群）753例と 比橭模封した。【結果】男女比はA群50/55、日群428/325 であった.占居部位はA群で A22 例、T13 例、D 03 例、S21例、 R46例，B群でA118例，T44例，D23例，S152例、R416例であっ た.stagoはA群で I 146例、II 38例、林 25 例、IV 9 例、V19例、

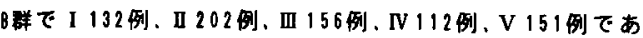

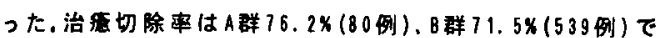

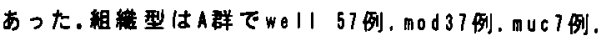
poorなく、日群でW日11386例, nod303例，muc34例, poor21 列であった.イレウスはA群26\%(27例)、B群17x(126(例)と

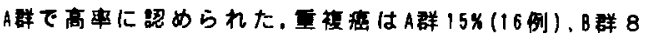
X(62例)でA群に多く、多器标はA群 $3 \times(4$ 例)、B群 6 \% (46列)であった。治瘾切除症例の5年生存审はA群69.0

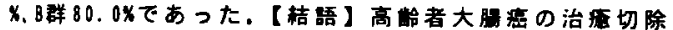

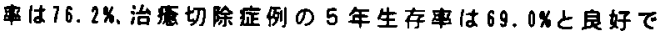
あり、秘㖶的な治切除施行が更要であると思われた。

523

高龄者に対する腹会陰式直腸切断術の

検討

岐鼻県匽生連久美要病院外科

○北川雄一、用岡伸柎、渡透智仁、三浦 敦、

田近微也、政井治

侵望の大きな消化器手術でるる腹会唅式直腸切断術 (以下APR)の、高鞈者への影整を若年者と比較検討した。 最近5年間に当院で根治術を施行した直晹害55例のう ち26例(47.3\%)にAPRを施行した。このうちアルコール依 存庭の1例を除く25例につき、年辪別にA・B 2群に分け 比较した。A群は70〜81虔の14例、B群は57〜 69歳の11例、

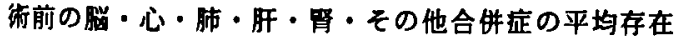
数は、A群2.4/B群1.1(以下A群/B群)であった。術後の合 併应数は3.5/1.6、排尿または性機能障害は2/3例であ った。また、Physiological and Operative Severity Score for the enUmeration of Motality and mobidity (POSSUM)のphysiological scoreは69.5/37.5点ておった。 程口摃取の開始までの日数は5.21/6.41日、術後在院日 数は64.9/55.7日であった。A群で、術前より3つ以上の 合件应を有する症例に限って検討すると、術後合併应 の発生が多く、経口取取の開始までの期間 - 在院日数 が長かった。高舲者で術前から多くの合併症を有する 症例では、䔔応および術中術後管理に充分注意する必 要かおると考えられた。
日本大学第 3 外科

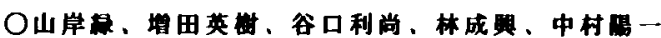

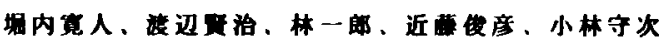
岩井重富、如掌索、田中隆

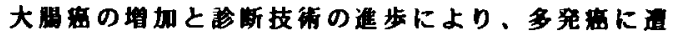

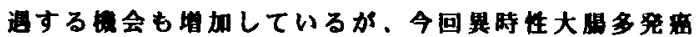

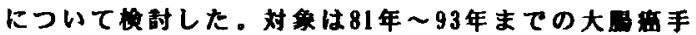

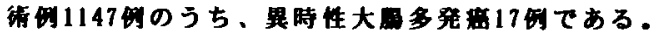

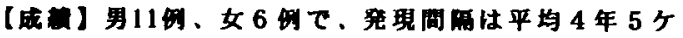

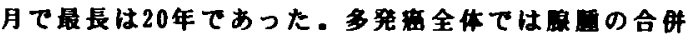

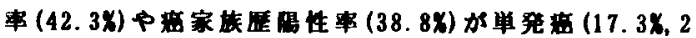
8.0X)に比数して有意に高率であったが、異時性(23.5

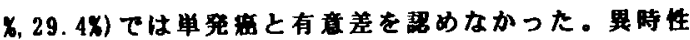

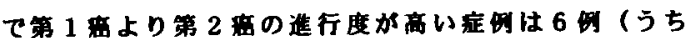

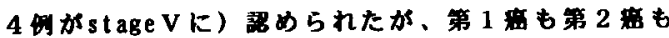

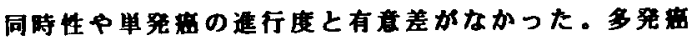

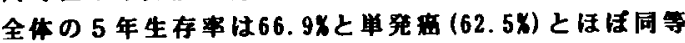
であったが、異时性 (27.7X)では予钐不良であった。

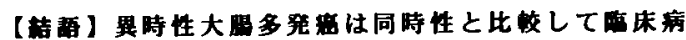
理学的相連点も少なくなく、予圜も不良であるか、第 2 需の早期発見が予铍向上につながると考えられた。

525

症例の検討

鳥取大学第一外科, 山陪䟫災病院外科 ${ }^{1}$

○倉吉和夫，中村誠一，牧野正人，木村 佟,

貝原信明，岡本恒之"

今回、我々は、当科にて経験した直腸カルチノイド 5 症例を対象として、臨床病理学的所見ならびに、核 D N A 量の面からその生物学的覀性度に関し検討を加 えたので報告する。梁達度はm 1 例、 $\mathrm{sm} 2$ 例、 $\mathrm{pm} 1$ 例 si 1 例でありs地下 3 症例では転移は認められなか ったが、深達度がpn以上の 2 症例ではリンパ節転移、 多発肝転移が認められた。 sm以下の症例には再発は認 められずp四以上の症例では肝転移巣に対して肝動注㞠 法を施行し、術後 8 ケ月、1 年 9 ケ月の現在、転移巣 の著明な腫大も認められず健在である。核D N A 量は 全例diploidy（S期7.53\%、G2/M期、5.65\%) であり、 aneuploidyの出現頻度は直腸煌の71.1\%(170/239)に 比べて、有意に低率であった。また、S 期ならびに G2/M期比率は転移の有無により有意な差は認められな かった。直腸カルチノイドの予後は一般に良好とされ ているが、自験例の核D N A 量はすべてdiploidyであ り、直腸カルチノイドは核D N A 量の面からも生物学 的悪性度は低いものと考えられる。 
恰对

富山県立中央病院外科

○下和久、小西金司、离田理、堀川直格、 長谷部健、川村泰一、津川浩一的、前田基一、 黑田吉隆、过政彦

術前にイレウス症状を呈した大脇盘95例を対象とし、 隐病理学的所見、予後につき、非イレウス例805例と

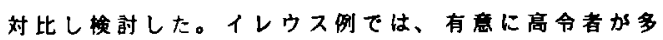

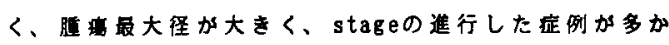
った。イレウス例全体の予後は有意に不良であったが、 治切除例で比較すると、非イレウス例と差がな良 好でった。晹管吻合か行われたイレウス例86利のち

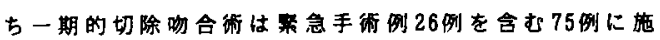
行され、䋖合不全発生例は4例（5.3\%)であった。4例中 3例は直閔低位前方切除術か施行されていた。二期的手 術例11例には、楗合不全の発生はなかった。在院死亡 は12例琶めたか、死7例、術前からのsepsisによるM OF死か 5 例であり、綎合不全が致命的となった症例はな かった。イレウス例に对する術式として、直渴息以外 の应测て治切除か可能でり、かつ全身状態が良好 ならぱ、一期的切除吻合徒が有用であると考えられた。

石川県立中央扈院一消化器外科

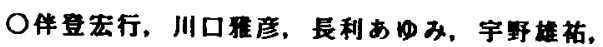

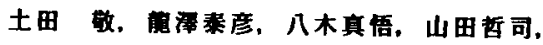

北川 晋, 中川正图

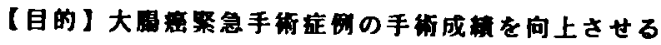

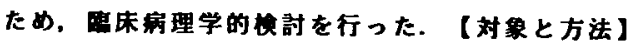

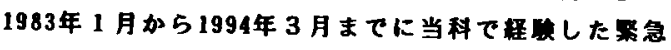

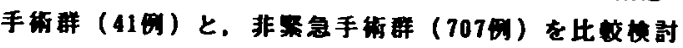

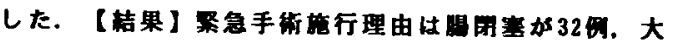

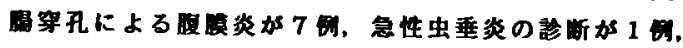

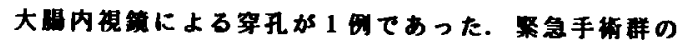

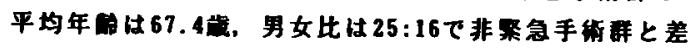

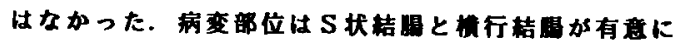

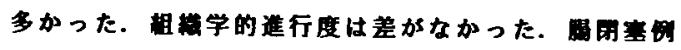

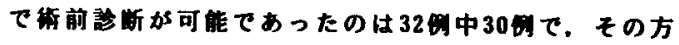

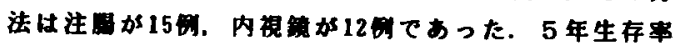

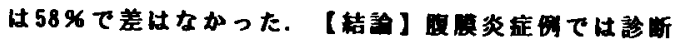

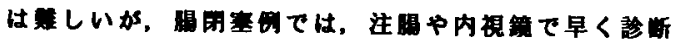
するのが重要であった。右㜀結国では一期的切除。物 合が可能で。左成桔用ではcovering colostouyを造設 するのが入院期间の短橧に有効であった。

\section{大垣市民病院 外科}

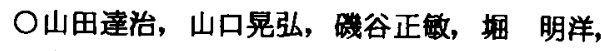
金 祐鎬, 前田敦行, 河合正已，高野 学， 山口竜三, 泣田智行, 松永和哉, 横山幸浩

大陽癌穿孔には，癌病巣自体の穿孔と密の口侧の 大腸が穿孔する場合がある。蹯の口側大湯穿孔は，

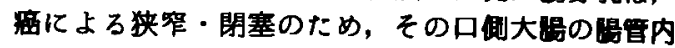
压が上昇し案孔するもので，閉塞生腸炎や宿便性洏

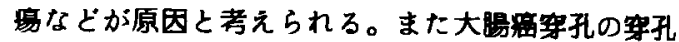

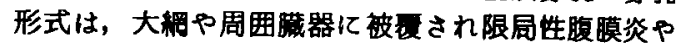

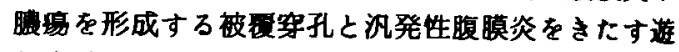
離穿孔とに分類される。

最近 18 年間に当科で施行した大䁑品手術症例数 1,830 列の 5 万大晹癌穿孔例は 64 例であり，そのう ち口側穿孔例は 21 例であった。その穿孔形式は被夏 穿孔が 5 例, 遊雄穿孔が 16 例であった。以上のよう

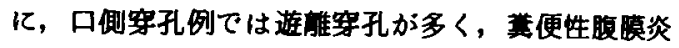
をきたしており術前全身状照が悪く予後も不良であ

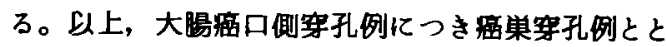
もに検討する。

挂川市立總合病院

加藤克己, 山本茂樹, 保里恵一, 羽萑誠記， 伊藤昭敏

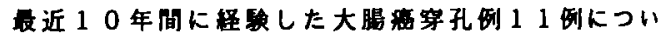
て惻討を加えた。

平均年略は72才であり、男性 7 例、女性 4 例であ

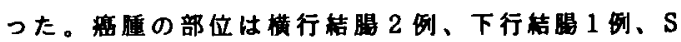

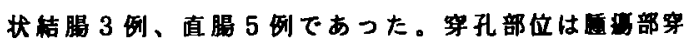

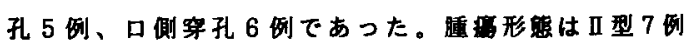
、III 型 1 例、不明 3 例であった。stage分斯を見ると II 1 例、III 2 例、IV 1 例、V 6 例、不明 1 例であった

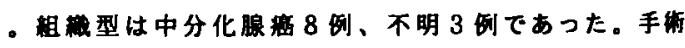
術式は一期的切除再建が 2 例、原场を㻌し人工仜門 を造設したものが 2 例（1例は 2 期的に再建）、人工 肛門のみ造設したものが 3 例、人工肛門造設视、2 期 的に切除を行なったものが 4 例（再建は 3 例）であっ た。リンパ節部清の程度は $\mathrm{R}_{1} 2$ 例、 $\mathrm{R}_{2} 4$ 列、 $\mathrm{R}_{3} 2$ 例であった。11例のうち1例が手㮊死亡となった。

大腸籍穿孔の治富にあたっては救命を第一に考え、 さらには雷眼治と思者のQ0Lを考慮した手街を塄抧す べきと思われた。 
店例の検討

\author{
岐鼻市民病院外科 \\ ○大下裕夫，田中千凯，種村廣巳
}

【はじめに】過去 10 年間に当科で切除された大陽的 458

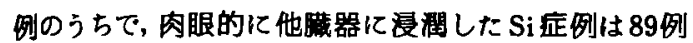

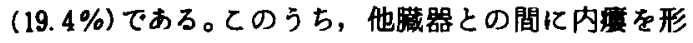
成した 8 例 ( $1.7 \%)$ の蹦床病理学的検討を行なった。 【結果】牛別は男生 3 列, 女性 5例。年龄は 29 89感で, 70 瓷以上の症例が 5 例みられた。瘦の占居部位は左側 大隄に多く, Rs 3例, S 2例, D 1例, T 1例, A 1例であ った。内眼型は3型 6 例, 2 型 2 例でおった。腫影最大

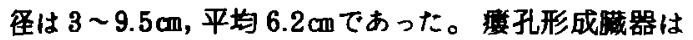
膀肤 2 例，子宫 2 例，小腸 1 例，結陽 1 例，十二指腸 1

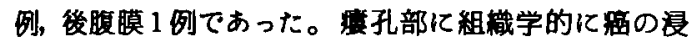
澗が証明された症例は 4 例であった。隀㻛の組樴型は 高分化腺瘦 5 例, 中分化腺痹 2 例, 低分化腺癌 1 例て おった。リンパ節転移は6例(75\%)にみられ，n14 例， n2 2 例であった。肝転移や腹膜転移はみられなかっ た。治富切除は6例で, 2 例は 8 年以上生存した。

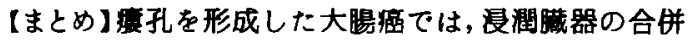
切除注っって予後の向上が期待できる。

531 $\mathrm{S}$ 状結腸癌、膀胼合併切除例における 回渴U字型 open flap法による膀脱 augmentation と 有莁大網を用いた骨盤底修復

\section{弘前大学第 2 外科}

○森田隆幸、中村文彦、伊藤 卓、鈴木 純、今 充

症例は60歳、男性、膀腅への高度浸潤を伴 $5 \mathrm{~S}$ 状結 渴㾌例である。上部直腸にも早期痁の併存を認めたた め術式は膀胱頸部以下を温存した膀胼合併切除十低位 前方切除術とし、直腸はdouble stapling法にて再建、 膀脱はGoodwin法に準じたU字型有茥回腸 open flap を用いて再建した。すなわち、直腸再建後、回腸末端 より口㑡約 $40 \mathrm{~cm}$ と60 cm の部位で回腸を切離し長さ $20 \mathrm{~cm}$ の有䒹腸管を得、乙れを $4-0$ 吸収系で墏膜箭層結節 維合を行いU字型腸管とした。次いで、U字型に腸管 を切開し内側縁を連続䋖合して open flap を作製、 Gambee法により膀胱頊部と释合した。なお、本例で

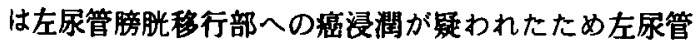
は同部で切離し回腸flap との吻合を行なっている。生

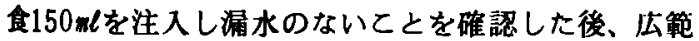
な骨盤底の腹膜欠損部は有荎大網を用いて修復し再建 膀胼之直腸の腹膜外化を図り良好な結果を得た。以上 の手技の実際をビデオにて供覧する。
国立がんセンター東病院外科

○新井竜夫, 小野正人, 谷山新次, 白井芳則, 杉藤正典，清家和裕，

症例は 59 歳, 女性。 ' 90,8 横行結腸癌に対し, 右半結腸切除施行（wel, se, n2, ly 2, v1, stage IIIb)。

'91, 8腹膜播種によるDouglas 腫蒖に対し，低位前方 切除術および両側卵巣摘除術施行。

'92.10仙骨前面の再発巣に対し，仙骨合併後方骨盤全 摘術施行。

' 93,10 腹壁の転移巣に対し，腫瘍摘出術施行。

'94，3腹膜播種による小腸閉塞に対し，小腸切除術施行。

以上のように合計 5 回の切除によって，現在も無症状 経過観察中である。いずれの手術の時も，肉眼的には 治癒的切除がなされているか，5回目の時はCTにて右 水肾症が確認され，その原因となっている切除不能の 右後腹膜腫晹速残があり姑息的手術に終わっている。

大腸癌はその生物学的特性により再発巣に対する根 治的切除か可能な場合も多い。今回この症例を検討し， 術後の定期検查の問題も含め再発大腸癌に対する治㞠 について検討した。

533 群碩十二指踖切除術を付加したS; 結 腸痓 5 症例の検討

東邦大学外科学第三請座

○崔勝隆、長尾二郎、炭山嘉伸、草地信也、

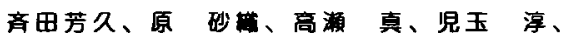

奥村千登里、白信弘成、清水茂金、神馬由宏、 本长達哉

結腸宣は他の消化器虚に比べて局所進展が特的て、

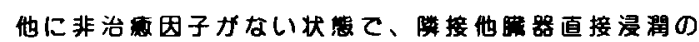
形霓を取ることが少なくない。S门結得臣は解剖学的

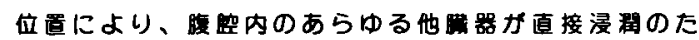
め合件切除の対象となり、手術術式は多汥にわたる。

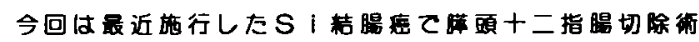
付加により切除し得た 5 症例について告する。

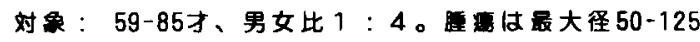
mm、絸型は高分化 4 例、低分化眼要 1 例。82才の男 性は患者の拒否で診断後 2 年10か月経週して手衙が施

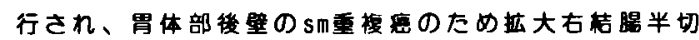
除術＋PD十胃亚全摘術を施行した。また64才の低分

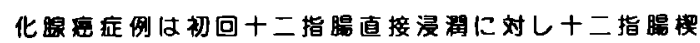

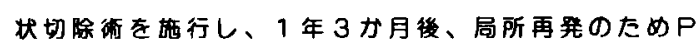

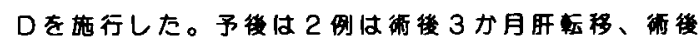
4 か月眐膜炎こ失つたが、他は術後 $49.25,13$ 力を経 週して再発無く経過している。 
运残直腸に発生した直渴禹の1

愛媛県立今治病院外科

○矢野達哉, 佐川 庸, 井上禎三, 窪園 隆,

廣瀬昌博, 坂東康生

直腸脱を来した非常に稀な S 状結腸瘦の 2 例を経耠 したので文献的考察を加えて報告する。

症例 1 は 57 墄、男性。半年程前より直腸脱あり、 近医にて整復していた。直腸脱か頻回におこるように なった為、当院を紹介される。初診時、肛門に直腸か 約 $5 \mathrm{~cm}$ 脱出、先端部に腫痽が認められ、整復困難であ り Rectosigmoidectomy 施行。組織学的には高分化腺癌 であり深達度はs、リンバ節転移はなかった。

症例 2 は 90 瓷、男性。 3 力月前上り直腸脱、下血 あり近医を受診、直腸脱を伴う大腸癌と診断され、当 院を稆介される。初診時、肛門に軽度の直腸脱を認め、 先端にBorrmann II 様の腫㿔を認めた。注腸及び大腸 ファイバーにてS 状結腸に径 $3 \mathrm{~cm}$ の腫㿔を認め、生検 では groupVであり Sigmoidectomy 施行。組織学的に

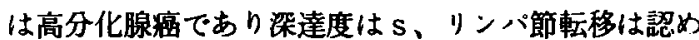
られなかった。

両症例とも術後経遄は良好であり、現在、再発の兆 候なく外来にて経過観察中である。

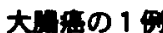

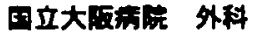

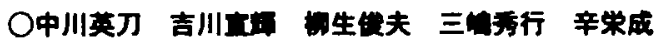

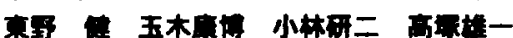

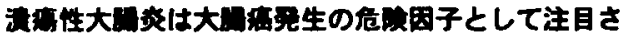

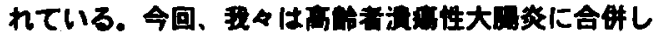

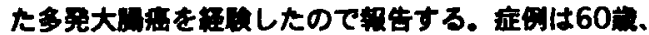

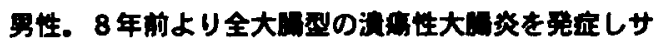

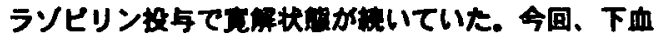

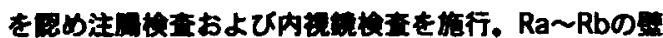

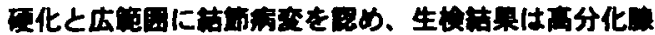

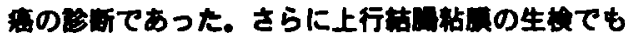

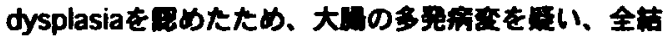

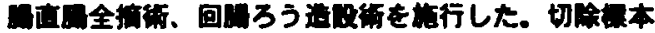

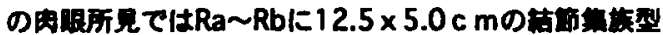

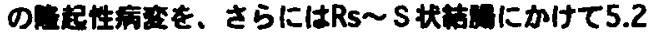

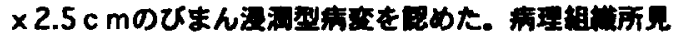

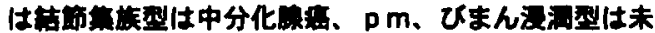

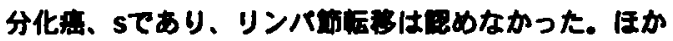

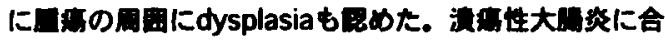

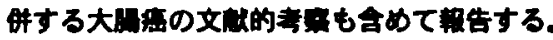

田川市立病院外科

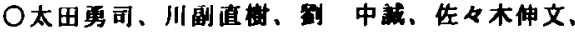
足立 兒

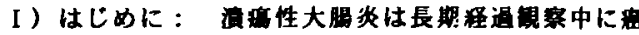
化することが知られ、䎶米では的 $6 \%$ に発賈をおこす

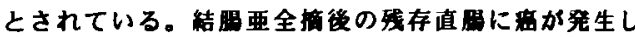
た症を経略したので啹する。

II）症例：患者は46才男性。主哌は妅閒部蒲。

既往歴、家族歴に特記すべきことなし。

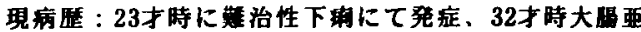

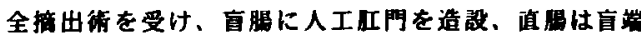
として放圈されていた。平成 5 年初めより、町門部有 が出現し精査入院となった。

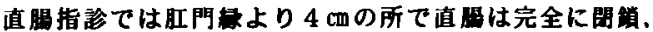

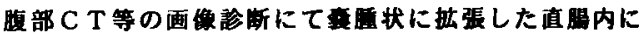

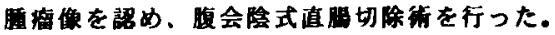

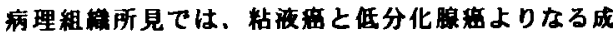
分がみられ、深達度は p mであった。

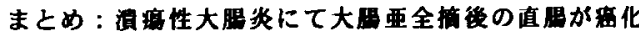
した症例は本的を含め文嗝的には本邦では 6 的で低分 化腺湆が多くみられる。

洛和会丸太町病院外科，京都府立医科大学第 2 外科* ○伊左治秀孝，谷俊男，山岸久一*

肛門癌は大腸癌の全体の約 2〜5\%といわれており。 庤㾣に合併した症例は極めて少ない。われわれは寿裳 に合併した肛門癌の1例を経験したので若千の文龒的 考察を加え報告する。

症例は78瓷，男性。高血圧にて当院内科に通院中，

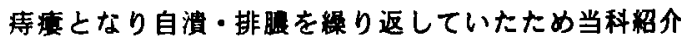
となった。局所所見では，畂門部右下㑡に庤视が認 められ，同部からの排脿かみられた。根治術の同意 が得られす，切開・排蛊を行いながら外来にて経迥 钼察中，肛門部に発赤を伴った睡翼を形成，しだいに 増大してきたため入院となった。同部の生梌組織診

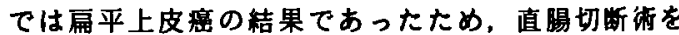
施行した。切除標本では直晹粘膜面には明かな病変 はないが，その割面では $4 \times 5 \mathrm{~cm} の$ 睡留が管外性に発育 しているのが認められ，庤痊に合併した肛門盘と思 われた。

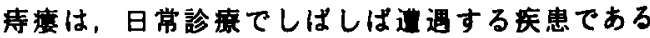
か，肛門癌の発生を念頭におき，皘極的に生検・手待 を考慮することか重要と思われた。 


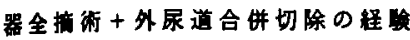

机科大学第一外科

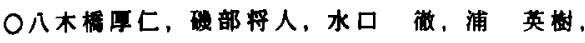

佐々木一晃，层野隆一，平田公一

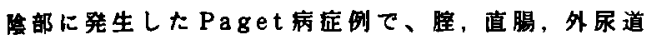

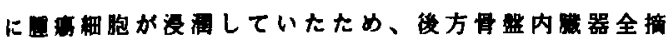
行外尿道合拼切除を施行した

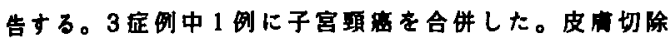

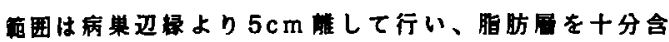
的切除した。通常、女性の外录道辰は $4 \mathrm{~cm}$ であるた、

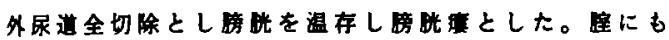

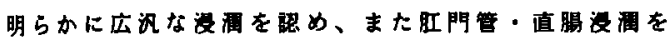

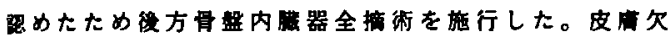
提部には植皮を行った。禹側最径リンバ節郭消を全例

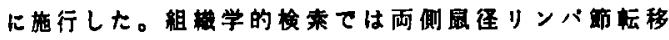

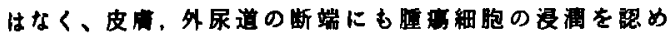
はかった。根治術を目標とした広籍团な切除において も、可能な限り機能温存を考慮することへの努力によ り、より良い手術を施行し得ると考えられた。

\section{爱知医科大学第一外科}

O三輪雅彦, 大岩靖典, 大輪芳裕, 永田 博, 松本幸三，鈴村和義，小島 卓，金光泰石， 小池明彦

最近私共は，原発性びまん浸潤型大腸癌を 3 例経験 した。【症例 $1 】 56$ 筬，女性，平成 4 年 2 月下血見ら れ近医受診、保存的治療にて一時軽快，同年 7 月賓血， 粘血便にて精查したとてろS状結腸に狭窄認め手術施 行, 肉眼所見壮 $\mathrm{H}_{3} P_{1} S_{8} N_{4}$ てあっった。術後 10 力月で 死亡した。【症例 $2 】 69$ 歳, 男性, 平成 5 年 2 月食欲 不振、腹部鈍痛にて当院内科検診. 精査したとてろ横 行結渴飞狭窄認也手術施行, 肉眼所見は $\mathrm{H}_{0} \mathrm{P}_{1} \mathrm{~S}_{2} \mathrm{~N}_{8}$ てあった。術後 7 カ死亡した.【症例3】57歳。 女性, 平成 5 年 11 月复気, 腹痛にて精査したとてろ上 行結晹に狭囬認め手術施行, 肉眼所見は $\mathrm{H}_{3} \mathrm{P}_{2} \mathrm{~S}_{8} \mathrm{~N}_{8}$ てあった。術後 3 力月現在生存.

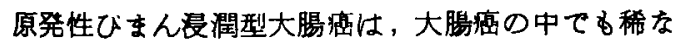
疶患てあり，また自覚症状が発現しにくく，診断時に は腹膜播腫やリンバ節転移を高率に伴い，特異的な肉 眼形態呈する予後不良な福であり，その臨床病理学 的特街につんて検討したのて報告する。
聖マリアンナ医科大学第一外科”、同第一病理 ${ }^{2}$ 、间第二病理 西川微、山村卓也、及川博、朝野隆之、小相公幸、山[1

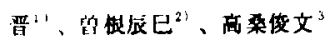

最大烽10 m以下のほとんどが早期知であり、進行䊩はまれで我

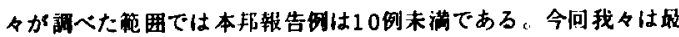

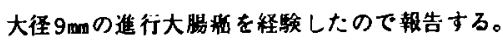

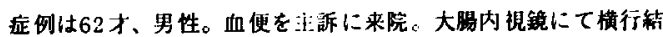

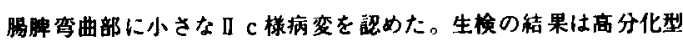
腺需であった。早期大腸船を疑い結晹部分切除術を施行した。脑 理所見では肉眼型が I a

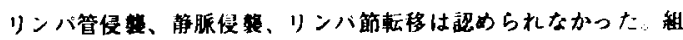

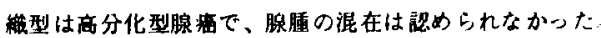

大晹船の発生様式にはA den om a'c ar cin oma sequence $と$ de novoが あり、いずれが圭たるルートであるかいまだ結詥がでていない。 本症例は小きな病変で、かつ腺腫を伴わない陌凹型の進行瘏であ るのでde·novo発生と思われる。しかし進行が框めて早いので通 炗の大渴瘦とは生物学的態度が異なる、特殊な大腸毒であると推 察される。

541

上行結晹腺内分泌密の 1 例

北海道大学第 1 外科

○富岡伸元 白戸博志 馬場策治 小橋重親

近藤正男 佐葠㭲二内野維一

夕張市立総合病院外科

後䔕洋一

近年, carcinoid 様の組織像を呈しながら極めて要 性度が高く，低分化腺學とも界なる内分汶顆粒を有す

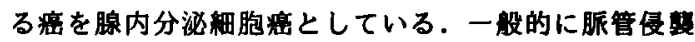
が高度で，早期から転移を起こし予後不良とされる。

当科において経験した症例は 63 胔，女性. 注渴パ リウムにて上行結腸に apple core signを認め, C F では 2 型の尰痛があり，細胞診は GroupVであった． 腫湶マーカーはCEA晹性, CA19-9 は陰性であった。

上行結腸㾇の術前晾断のもと，結晹右半切除術 (R3) を施行した. A, vent, 3 型, $8.2 \times 7.3 \mathrm{~cm}, S_{1}, N_{2}$, $\mathrm{P}_{0}, \mathrm{H}_{0}, \mathrm{M}(-)$, Stage Illa であった。病理組樴学的 所見は，ロせット形成，シート状の細胞配列，唘死を 伴うadenoendocrine cell carcinomaが大部分を占め, 一部に叛を認めた.深達度は $\mathrm{s} \mathrm{s}$ で， $\mathrm{n}_{0}, l \mathrm{y}_{1}, \mathrm{v}_{0}$ ， ow(-)，aw(-)， stage II であった。 
な肉眼形㮩を呈した大腸腫福の1切除例

浜松医大第一外科、同病理*

○石原行雄、木村泰三、吉田雅行 小林利彦、 桜町俊二、吉野䉆人、久保田修、川辺略浩、

踰木意次。原田幸嫶、喜秋 勇*

症例は58藏、男性。排便時出血を主訴に近医を受

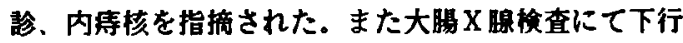
結膦に隆起性病変を指摘され当科紹介された。大睡内

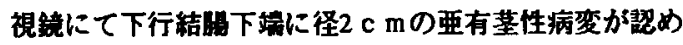

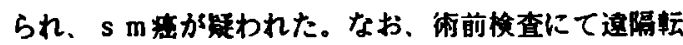
移は認められなかった。手雨は腹胵鏡補助下で行な い、下行結䀧切除とした。切除標本上，睡家は $2.0 \times$

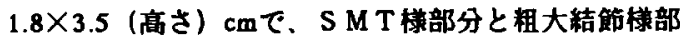

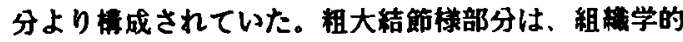
には大部分が中等度異型を呈した腺管腺腫であり、敞 在性に粘䀧内疼を伴っていた。また、S MT様部分は

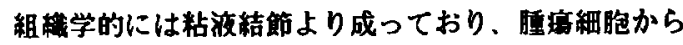
の粘液分泌か閔与していると考えられた。

防府消化器病センター、九州大学医学部第二病理 ${ }^{1}$

○公家健志，長䗁進、川野業一，松崎圭祐，三浦 北香滋郎，武内秀也，岡本史樹, 戸田智博, 南園義一, 八尾隆史 ${ }^{11}$

大腸癌の多くは分化度の高い腺密であるが、今回我 々は稀な腺扁平上皮症の 1 例を経検したので、文献的 考察を加えて報告する。症例は52才男性、便通異常、 肛門出血を主訴に来院した。胸腹部，表在リンパ節等 に異常を認めなかったか、直腸指診にて肛門縁から約 $3 \mathrm{~cm}$ 吅側に全周性の腫痛を触知した。大腸ファイ バーにて、腫痛から生検を行い、well differentiated adenocarcinoma の診断を得たため、腹会陰式直腸切 断術を施行した。術後の病理組織診断にて、未分化成 分を伴う腺扁平上皮息の診断を得た。

大腸の腺扁平上皮䍃は、検索し得た限りでは欧米51 例、本邦49例の発表があり、肛門管を除いた直腸下部 のものとしては、本症例は本邦第 3 例目と考えら机た。

1 例

昭和大学病院 外科

富田康弘，沿澤三喜，草野满夫

龟田総合病院 外科

清水和久。敛島恒司

大腸原発の神経鞘腫は比較的稀疾患てあり，その らち直腸原発の神経䩪盾は本邦において，我々の検卖 した限りにおいて自験例を含め19例てすを゙な。今回

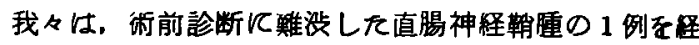
験したのて報告する。症例㤌67歳，女性。6力月前上 り腹部膨満感が出現し，最近上腹部痛ををたしたため， 平成 5 年11月15日当院受馀した。下部消化管造影ては 直腸 Rs 部儿往 $5 \mathrm{~cm}$ 大の粘瞙下睡婸か㠜われた。下部消

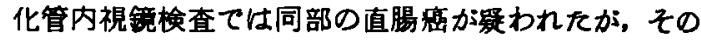
際得られた病理組織像からは診断は得られなかった。 腹部超音波検查, CT, MRI, 腹部血管造影飞上万検索 を和てなったか，特徽的な所見は得られなかった。直 腸稆を想定し，低位前方切除術 $\left(R_{2}\right)$ を施行した。摘出 標本の割面は粘膜下首に主座を持つ偠均一な黄白色 の充実性腫場で，免废組織染色では vimentin，s-100 蛋白が陽性で神経鞘腫と診断された。また核分裂像は認 められず艮性病变と考えられた。

545 大渴湿街俊学暴法により完全消失し

た多発性肝転移の1例

岩手県立福岡病院外科，同第 1 内科*

○阿部正，坂下伸夫，須腾隆之，西西直敏。

植田恪*

今回我々は，上行結胆要の多発性肝枟移に対して， 結胿切除後 2 度のIAEと UFT経口投与を行ない，所転 移果の完全消失が得られた 1 测を経梌したので報告す 万。

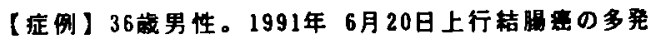

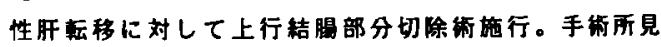

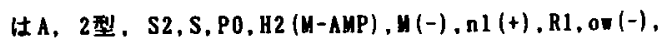

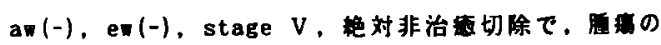

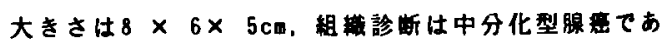
つた。術㣪早期から UFT600 $\mathrm{ng} /$ 日開始し、91年 7月15 日 MMC,EPIR,Lipiodo1,spongelを用いてTAEを柂行し た。その後肝枟移果の樎小奻果が認められたため、92 年 2月21日2回目の TAEを施行した。その後も転移紧 は縮小しつつけ，94年 4月完全に消失した。脸禹マー 力一江術前CEA $14 \mathrm{ng} / \mathrm{ml}, \mathrm{CA19}$-9 $1800 \mathrm{U} / \mathrm{ml}$ と異常高 值を示していたが。現在 CEA $2.1 \mathrm{ng} / \mathrm{al}$,CA19-9 11.5 U/四にと正常である。比较的稀有な症例と思われるのて 若干の文献的考察を加え報告する。 


\author{
系魚川総合病院外科、富山医科菻科大学第 2 外科 * \\ O鉿木修一郎、大西鲭康、增山喜一、沢田石 勝 \\ 坂本 㜢 $^{*}$
}

〈症例〉症例は 69 藏、男性。平成 5 年 9 月、大腸福 にて低位前方切除術を施行。腫鸱は(1)S-Rsおよび(2)そ の肛門側にあり、(1)は 2 型の腫場で肪胱および小腸に 浸雷しており、その合併切除を行なった。組緒診断は tub2, sei, 1y2, v1, n1(+), ow(-), aw(-) であった。 (2)は carcinoma in adenomaで、組織診断はpap-tubl,四であ った。街後、5Fuによる化学療法を施行した。術後 5 か月目、肝前区域より後区域にかけ肝転移および門脈 右枝の隀瑏栓が怹められた。平成 6 年 3 月、肝右葉切 除および門脤右枝より本幹にかけての腫鸱拴の除去を 行った。組綞猃断はpapillotubular adenocarcinoma で畽疡拴を有していた。〈考察〉所切除の手技の改善 とともに転移性肝䖽での肝切除は皘極的に行なわれて いるが、門脤内看韵栓を有する場合、その適応は限ら れてくる。今回、大晹程の術後、門㟲に腫榎栓を有す ろ轻移性肝癌に対し、肝右葉切除および腫瘍栓の除去 を行なったので、文献的考察を加え報告する。

清水市立病院 外科

O北伤正久、大作昌義、綿引洋一、丸尾啓敏、小坂昭夫 近年、㾇街後長期生存例の增加に伴い重複癌症例の 報告は增加㑯向にある。当科における大腸重複癌にお け3肝細胞癌の頪度は13例中 4 例（ $30.8 \%)$ と高率 であっだこの理由としては流行泩肝炎（與津肝炎）。 に伴うC 型肝炎患者が当地区に多いことが影锌してい， ると考えられ、4例中 3 例が H C V抗体陽泩であった

症例 $1: 71$ 歳、男性。同時性重複癌、S 状結腸癌と S 5 肝細胞窝。 H C V抗体陽性。

症例 $2: 69$ 嵅、男性。肝癌先行異時性重複椑、S 状 結腸癌とS5 6 肝細胞癌。H C V抗体陰性。

症例 $3: 63$ 歳、男性。大腸癌先行異時性重複㾇、 直腸窝とS 5 肝細胞癌。H C V抗体陽性。

应例 4 : 75瓷、女性。同時性重複癌、上行結腸癌と S 5 8 肝絧胞癌。H C V抗体陽性。

文献的には重複癌における大腸・肝の頻度は低く両 的切除の報告例は少ないが、自験例は 4 例とも切除 し 得た。予後としては 1 例のみが術後21力月で肝癌再発 死亡、他の症例は生存中である。 H C V抗体陽性の症 例に対しては、常に肝細胞梹合併を念頭において術前 診断および術後経過観察が必要と考えられた。

\section{国立習志野病院外科}

○亀高 尚、伊藤文雄、花输孝雄、山本和夫、 武田雄一、香田运一

最近我々は高龄者の同時性大腸重複癌の 2 例を経験し たので、文献的考察を加えて報告する。

〔症例 1〕79才女性。食欲不振、体重隇少を主訴に近医 にて胃透視をうけBorrmann2 型の腫留を認め、当科 入院。注腸造影にてRsに而型の腫留を認めた。胃及び 直腸の同時生重複癌の診断で、Billroth I 法による胃 切除術、直腸低位前方切除術を施行した。

【症例2〕79才女性。数年来の便通異常を主訴に直腸窝 の診断で当科紹介入院。大腸内視鏡にて Rsに П型の腫 瘤を認めた。また、胃内視鏡で园体中部大弯侧に宿凹 性病变認め、生検にて胃癌と診断、同時性重複癌とし て直腸切除術、胃体中部拁状切除術を施行した。 〔考察〕大腸と他瀻器の同時性重複癌では胃との重複癌 が最も多いという報告がある。当院の過去 5 年間におけ るデータもそれを裏つけるものであり、術前の椱数䑏 器のスクリーニングは非常に大切である。診断後も全 身状態、病紧の進行度を考虑し、適切な術式を選へば 一期的な手術も可能であると考える。

549

早期胃案・大腸悹・悪性リンバ腫の同 時性 3 重複腫場の臨床経過

演病院外科, 和歌山県立医科大学消化器外科” ○柏木秀夫, 治 正純, 潰 光治, 谷村 弘, 永井枯吾”,

澽藤克也，山本基”，野口浩平”

症例は72歳の女性。全身倦点感と微熱を訴え，近医 にて内規鏡検査で胃㮫と診断され，1993年6月15日胃 切除術を施行した。前庭部小弯の $2 \times 3 \mathrm{~cm}$ の I 病变で, 組織診断は印環細胞密， m, noであった。術後し CEA が $13.5 \mathrm{ng} / \mathrm{ml}$ と高值のため，術後1カ月目に注腸と大腸

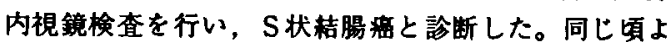
り $39^{\circ}$ Cの発熱と咽頭に腫湯性病変を認めたが、下血も 出现したため7月28日 S 状䠜腸切除術を施行した。腫 蜴は $43 \times 45 \mathrm{~cm}$ の限局溃場型で，組織診断では中分化 腺瘦，ssであったが，壁在リンバ節のうち1個は我の 転移で,それ以外はnon-Hodgkin lymphoma, T-cell, diffuse, large œll typeであった。8月5日和歌山医大外科 に転院したが，全身状態不良のため化学瘄法を行えず， 8月18日死亡した。病理解剖では両肺, 副堅, 咽頭, 随膜に悪性リンパ看を認めた。 
家系にみられた子宮体癌の検討

一本邦報告例の検討および国際共同研究報告一

星総合病院外科，福島県立医科大学第二外科，

兵庫医科大学第二外科

○野水 整, 八巻義雄, 音田正光, 渡辺文明, 佐藤久芳, 土屋敦雄, 阿部力哉, 宇都宮撞二

H N P C C 家系においては大腸癌以外にもいろいろ な悪性腫瘍が高頻度に発生する。なかでも子宮体癌は 大腸癌に次いで発生頻度が高い。1992年までの本 邦報告H N P C C 家系では 9 家系 1 0例の子宮体癌の 報告があった。7例が大腸癌との重複で5例が大腸癌 先行であった。診断時年粭は平均 46 歳で対照とした 一般子宮体癌（福島県立医科大学産婦人科症例）に比 べ若年性であった。重複大腸癌は 39 歳、H N P C C 大腸癌全体では43葴であった。7ケ国（フメリカ、 オランダ、カナタ、スイス、日本、ニュージーランド フィンランド) の共同研究 122 例の検討でもほぼ同 じような結果であった。

ド腄瘦を発症したガードナー症候群の1例 岡山赤十字病院外科

○大西洋一，小野監作，寺本浑，池田英二，内蒌稳 山田真人，过 尚志，古谷四郎，川上俊爾，大塚康吉

今回我々は，家㭠性大腸ポリポーシス(以下FPC)及ひ

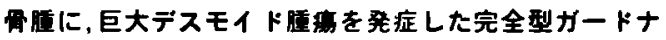
一症候群を程楼したので報告する。

〈症例〉26才女性。家族歴にはFPCを認めない。23才の

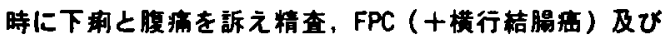
下預骨の骨原を証めた。平成3年4月，全結腸切除，回

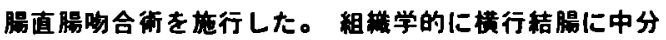

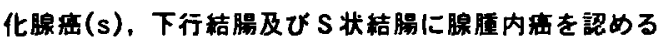
FPCであった。平成5年3月に腹部缰展を認めたが，その 後奸娠が判明した。本人が出産を希望したため経過销 察し，平成6年1月に自然分婏にて出産した。同年2月の

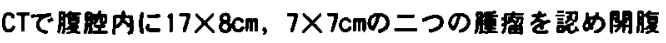

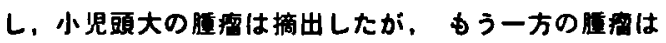
回腸直腸吻合部に接しているため摘出しなかった。組 機学的には，小腸間膜内のデスモイド腫嫁であった。 街後Linacを total 40Gy照射L, 内服治瘄( tamoxifen, sul indac, ascorbic acid)を行なった。平成6年4月に轻 快退院した。

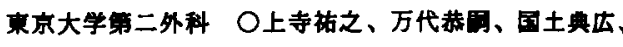

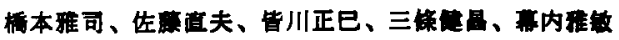

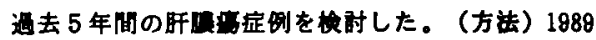

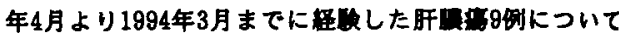

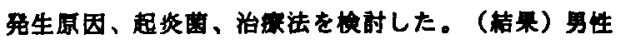
8例、女性1例であり、年令は22-68才(平均51才)であっ

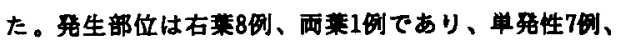
多発性2例であった。発生原因は、RTBDチープ2例、原発

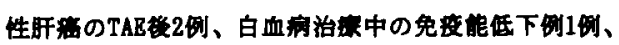

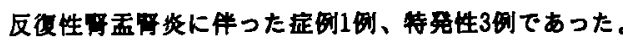

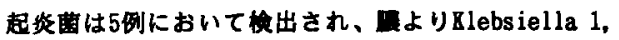
B. coli 1, Serratia 1, Pseudomonas aeruginosa 1 , Pusobacterium 1, Bnterococcus 2, GPR 1が、血液より Serratia 1, Bacteroides 1が模出された。治萧法は、

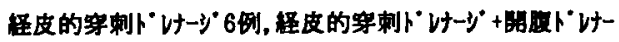

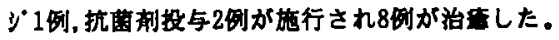

（まとめ）1、9例中5例では、RTBDキュープ、TAR、白血病 の化学家法等の原疾患に詨する治落行为が原因となっ ていた。2、本庭の原因として鿓気性菌が重要とされて

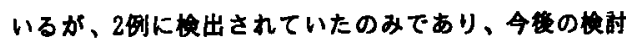
が必要である。

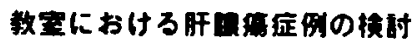

金沢大学第 2 外科

○安居利界、宣原正衩、谷口挂三、月网始治、 太田暂生、上纾挂一、永川宅和、宫峿这夫

[目的およひ对来] 1979年から1993年までに掼で

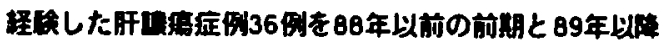

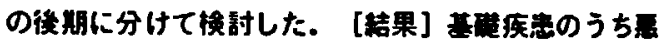
性疾患は前期では22例中8例(36\%)であったが、後䩗で は14国中19 79\%)と有意に(p<0.05)堷加し、16休

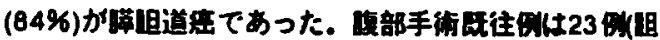

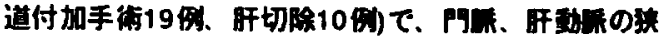

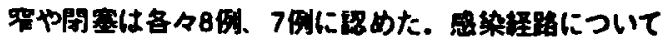

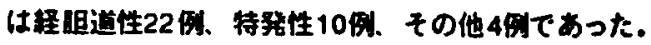
起因菌のうちKlebsiellaが䄪半数に换出されたか、、後期 ではEnterococcusの增加が目立ち、92年以陵はMRSA

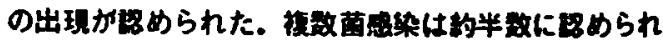

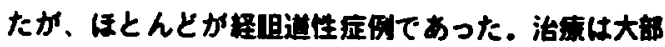
分の症例にPTADが施行されているが、旰国息に退因

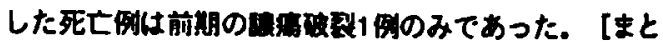

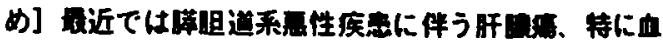

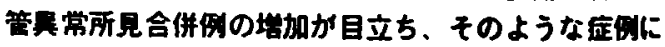

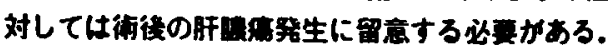


草加市立病院外科

○星野直明、小成臀太、西村 久閶、今城直人 八重摼竟治、

化朖性肝晨瘍は重第な病態に陥る感染症のひとつ である。我々は、過去 6 年間に 7 例の化膔性肝䝢湟

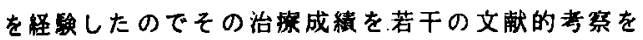
加えて報告する。年令は 36 歳から 79 煘で平均 6 4.6 蜦、男女比は 4:3であった。7症例中 4 例 で急性胆亳炎の合併を認め、また胆石症の合併を 5 症例に諗めた。また総胆管結石術後と経カテーテル 肝動脈塞栓術（T A E ）後の肝滕湯発生をそれぞれ 1 例ずつ経弱した。診断においては超音波、C T が 有用であった。治療は 5 例には開渡ドレナージを 施行、2 例には超音波誘迸下膿清穿刺ドレナージ( P T A D ) を施行した。治療経過は全例において良 好であった。本症は高龄者の胆零炎に合併しやすく 、また敗血症など重篇な病態に移行しゃすいため早

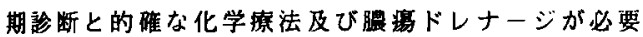
と考えられる。

555 肝咅胞性腫埸切除例の臨床病理学的検討 大阪市立大学第二外科"), 病院病理部 ${ }^{21}$, 第二病理 ${ }^{3)}$ O村制順哉，木下博明，広橋一裕，久保正二, 首藤太一，

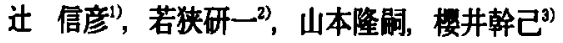

【目的】肝咅胞性腫場において, 肝襄胞腺腫之腺癌の 篮別は困難で，その確定診断は病理組織学的検査にた よらざるをえないそここで当科において切除された肝 䡠胞腺腫およひ腺癌症例を検討した。【方法】対象は 過去11年間に当科で切除された肝霓胞腺腫 5 例, 腺癌 2 例で，これらを血液検查，画像，内容液の性状，病 理組樴学的所見を中心に比較検討した，【結果】平均 年龄，性別は襄胞腺腫55.6歳，男1例女4例，妻胞腺癌 70.5歳，男 1 例女 1 例であった。術前の血液検查に異 常値は見られず，画像診断上，腫場径，隔壁や充実性 部分の有無に差はみられなかったが，腺癌の 1 例に経 時的な腫惶性状の変化が見られた。内容液は腺腫の 5

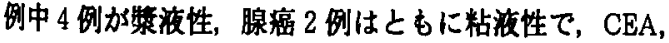
CA 19-9值は両群とも高值を示した．病理組織学的所 見上，腺癌において，粘液産生と襄胞壁およひ充実性 部分の粠成細胞に異型性がみられた。【結語】画像所 見て肝要胞腺腫・腺癌の鑑別は困難であったため，肝 暻胞性腫湯に対して悪性を否定しえない場合，䀒切除 を選択する必要があると考えられた。

$$
\text { コレステロール結石症の一例 }
$$

東邦大学医学部外科学第三講座

東邦大学医学部付属大橋病院病理部 $*$

平野良治、碓井貞仁、桜井貞夫、武田明芳、柁原宏久 中村光彦、中村順哉、渡辺学、炭山需伸、

直江史郎*

症例 65 歳，男性. 平成5年12月他院にて䅡窒资にて回 盲部切除を施行した，術媵経過は良好であったが、平成 6 年1月下旬より $38 \sim 39^{\circ} \mathrm{C}$ の発熟が認められた.US、CT

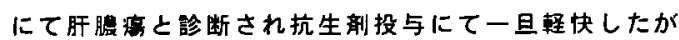
再度発秇したため，同年3月精查目的にて当科紹介入院 となった，入院後のUSで肝外側区域に径約 $4 \mathrm{~cm}$ の内部 echo不均一で一部cysticな像を呈する䐬㩧と約 $5 \mathrm{~mm}$ 大のstrong echoが認められ結石の存在も疑われた

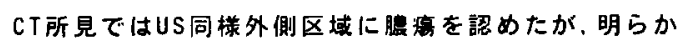
な結石等は見られなかった. ERCでは肝外側区域胆管 枝(B2．３）の数珠状の拡張変化を認めるのみで、他に 異常所見は得られなかった.US下穿刺トレナージにて 下熱したが同時に行った、滕汁培嗕にてKlebsiella が検出された。同年3月29日肝外側区域切除を行った 胆管内に径 $5 \mathrm{~mm}$ 大のコ系石を認め，またその末梢胆管 を中心に広範な填死像と絨維化が見られた

大阪市立大学第 1 外科

西村重彦，西野裕二、大平雅一，有本裕一，新田教篹。 山田靖哉。竹内一浩, 澤胃, 柳川一，康純明。 高塚 聡、清水貞利、山本 䉀、池原照幸、兽和融生

最近10年汫で経験した肝細胞痘切除例52例を 1 年以内 再発群13例。1年以降再発群14例。無再発群25例に分 けて、手術所見、病理学的所見について検討した.【結 果】各群の治㾰切除例は7例 $(61.5 \%)$ ，13例（92.9 \%) 、 24例（96\%）で. Stage IIINはそれそれ8例 (61.5\%)，1例（7\%），3例（12\%）であった．䭪 㾔径別では特に差は認められなかった. 病理学的所見 では再発例で低分化型，末分化型肝細胞凐が多く認め られた。また、vp陽性例は 1 年以内再発群7例。1 年以 降再発群2例。無再発群2例と1年以内再発群で有意に 多く、im陽性例は 1 年以内再発群6 例、 1 年以降再発群 2例。無再発群6例で，Im2以上の5例はすべて 1 年以内 に再発していた. 他の病理学的所見（fcint,tw）の梌 討では特に差は認められなかった、【結語】肝細胞痘 切除術後 1 年以内再発例は非治痹切除例. Stage II $\mathrm{N}$ 症例が多く、また，vp陽性例，im2以上の症例では 術後比較的早期に再発が認められることが多かった。 
日本大学第 1 外科

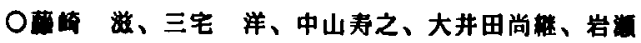
正明、天野定椎、水野敏重、黑須廉

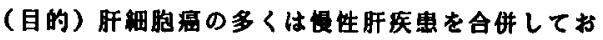
り、切除后囲は肝予備能の程度により制限を受ける。

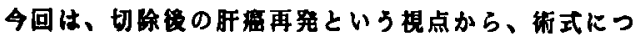
いて熶时した。（対象）1988年1月から1993年12月まて

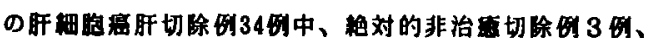

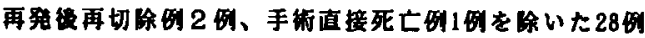

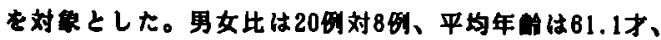

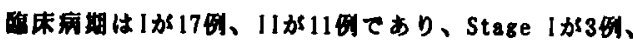

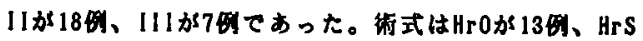

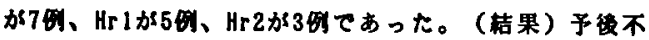

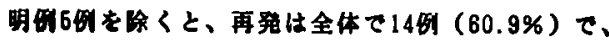

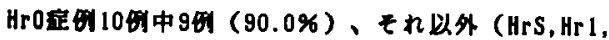
Hr2）の在国136中5\% (38.5\%) てあった。なお、再

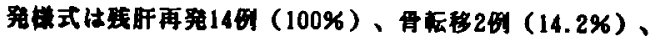

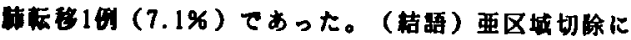
いたらない切除は再発が多くみられ、街後の再発予防

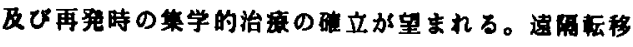
にす留意する必要がある。

559 肝細胞癌切除術後の再発症例の検討 北海道消化器科病院外科 ${ }^{11}$ 、同 内科 ${ }^{2)}$ 北海道大学第 2 外科 ${ }^{3)}$

○大柏秀樹" 、西山 徹 ${ }^{\prime \prime} 、$ 宮坂祐司 ${ }^{1} 、$ 藤田美芳 ${ }^{\prime \prime} 、$ 森田高行 ${ }^{2}$ 、吉田達也 ${ }^{2)} 、$ 合田峰千2)、井上善之 ${ }^{2)}$ 、 宮坂史路2)、目黒高志 ${ }^{2)}$ 、西沢正明2)、堀田彰—2) 下沢英二 3，加藤䌕之 ${ }^{31}$

肝細胞癌切除例において再発病態を知るへくく臨床病 理学的諸因子を検討した。

対象は最近 5 年間に当科で切除した肝細胞癌症例 31 例てある。方法は肝細胞癌切除例を再発群と無再発群 の2群にわけ、HBs 抗原およびHCV抗体陽性率、肝硬 変の有無、腫瘍マーカー、病理組織学的所見につレて 比較検討した。各因子の有意差は $\chi^{2}$ 検定によった。 再発は17例に認め、再発率は54.8\%であった。再発 時期は平均 19.2 っ月てあった。再発様式は残肝再発16 例 (単発12例、多発 4 例)、肝外再発 4 例 (副腎、リン 八゙節、肺、骨)であった。再発因子は200以上の AFP 高度陽性例が再発群て有意に多く、腫場径が $2 \mathrm{~cm} よ り$ 大きい症例と門脈侵蜜を有する症例は再発群て多い傾 向を認めた。再発後の治療は再切除7例、TAE 8例、

$\mathrm{TAE}+\mathrm{PEIT} 2$ 例てあった。

AFP 值200以上、腫葟径が $2 \mathrm{~cm}$ より大門脈侵䘫を 有することが再発危険因子と考えられた。

\section{と解離電流の同時通電法によるマイクロ波挰固㬌法}

\section{国立大阪南病院外科}

○森一成，田伏克恛，杉本恵洋，计 教，

岡 正已, 朝野 聡, 尾䓫 敬, 平井久也

マイクロ波（MW）と解蜼電流（DC）を同時通電す ると，従来のMWだけの通奄に比へ，効率よく組䋘を 熱凝固できる。そこで，この新しい方式て肝癌街後再 発病柴のマイクロ波癞固を行い，効果を検討した。

方法 : 外径1.6mmの電栖をUS下に残肝再発病巣内，

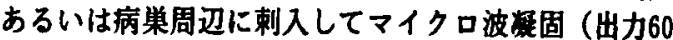
ワット)し，CTで平価した。

成嘖 : 1993. 8より，治㾻個数が $2 \sim 4$ 個の 4 症例に， 局所席䣲下の経皮的治暴を 9 回，全身麻醉下の経皮的 治療 1 回, 開胸経横隔膜的治療 1 回の計11回施行した. 1 病竹につき20分間（30秒間歇20回）通電できた 7 回

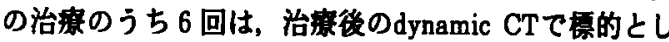
た病巣のtumor stainが消失あるいは不明㛺になり，最 大限，徍 $3 \mathrm{~cm}$ のCT変化を㑇めた.

結諭 : MW，DC同時通電方式を用い、低出力,間歇照 射法で従来のものより有効な凝固治效ができることを 認めた。

北海道大学医学部第 1 外科

○松下通明、宇根良街、中島保明、佐藤直橵、神山

俊哉、鸠村 㓮、壳木茂、西部学、中西一竞、 檄井経徳、中川隆公、秦 府壮、内野維一

肝細胞空(HCC)の他㬴器転移としては、肺に最も好 発するが、転移巣が単発、多発、両葉再発のことがあ り、その治瘱法の選択は必ずしも简単なものではない。 そこて 1989年5月から1994年4月の5年間に経的したHCC 肺転移例5例を対解に、外科治療法の造択とその予传を 検討した。症例は32〜62嵅の全例男性であった。初回 肝切除時のHCCは、中分化型4例、低分化型1例であり、 再発形式は、片菜単発2例、同時性両葉単発1例、同時性 両葉多発 1 例、異時性両葉多発1例であった。手術は、 肺葉切除 4 症例 5 回、部分切除2症例 3 回を行った。部分 切除は、転移巣が 直径 $1.5 \mathrm{~cm}$ 以下の末梢型の症例であ り、全例胸腔鏡下で肺切除を行い、维後早期に回復を みた。予後は、5例中3例が生存中て、初回肝切除後平 均3年8力月 (最長 7 年 3 力月)、初回肺切除後平均 1 年8 月(最長4年)であった。HCCの肺転移は切除により、著

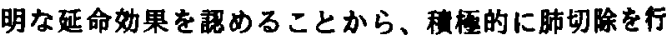
うベきである。 